\title{
Priority directions of development "Uzbekneftegas" jsc in the conditions of globalization of the world economy
}

\author{
G.Zh. Allaeva ${ }^{1}$ \\ ${ }^{1}$ Tashkent State Technical University named after Islam Karimov, 100095, Uzbekistan, Tashkent, University St. 2A
}

\begin{abstract}
The article considers the role of "Uzbekneftegas" JSC in the economic development of the fuel and energy complex of the Republic in the face of increasing global economic globalization. The structure of the company, the priority areas for the development of JSC activities are shown. The perspective directions in hydrocarbon production are considered. The data on the production, use and distribution of natural gas by sectors of the economy of Uzbekistan are presented, and the structure of the energy balance of the Republic of Uzbekistan is shown.
\end{abstract}

\section{Introduction}

The increasing demand for hydrocarbons in the world and rising prices for oil and gas raw materials make Uzbekistan one of the important participants in the global energy market. The energy policy of Uzbekistan in the context of the increasing globalization of the world economy is primarily aimed at ensuring energy independence and security, increasing energy efficiency and reducing the environmental impact of energy. In order to increase the level of independence, maximize profits and, accordingly, further economic development, our state seeks to diversify energy export flows. "Uzbekneftegas" JSC takes a leading place in the implementation of this policy.

For the effective economic development of the fuel and energy complex of the Republic of Uzbekistan, it is necessary to modernize the currently inefficient, morally and physically obsolete equipment in the industry with modern energy-efficient and energy-saving equipment, it is necessary to optimize the production process in large and medium-sized enterprises. In the energy sector, these are gas-turbine and combined-cycle plants, combined generation of heat and electric energy, an increase in the oil and gas extraction coefficient and an increase in the efficiency of their processing and transportation, enrichment of coal at the extraction site and the introduction of effective technologies for its combustion, reduction of losses for domestic needs, and an adjustable electric drive and etc.

\section{Analysis of the main economic indicators of development of “Uzbekneftegaz" JSC}

In Uzbekistan, "Uzbekneftegaz" Joint-Stock Company (JSC) deals with the production of hydrocarbons and providing with them industries and the population. "Uzbekneftegaz" JSC is a vertically integrated threelevel company. The current company management system was approved in accordance with the resolution of the President of the Republic of Uzbekistan in 2006 [1]. The company includes 6 Joint Stock companies engaged in geological exploration, drilling of oil and gas wells, oil, gas and gas condensate, natural gas processing: "Uzburneftegas" JSC, "Uzneftegasdobycha" JSC, "Uztransgas" JSC, "Uznefteproduct" JSC, "Uzneftegazstroyinvest" JSC, "Uzneftegasmash" JSC.

The capacities of "Uzbekneftegaz" JSC allow for the production of natural gas in the amount of about 70 billion $\mathrm{m}^{3}$ and liquid hydrocarbons in the amount of 8 million tons/year [1]. To further stabilize and increase the growth in oil production, "Uzbekneftegaz" JSC has launched the "Concept for the development of the oil and gas industry of Uzbekistan until 2020", which provides for an increase in hydrocarbon reserves by 2020 compared to 2010 by 1.25 times for gas and for oil in 1.65 times, condensate - 1.33 times. It is planned to increase the annual volumes of prospecting, exploration and parametric drilling 2.5 times and reach 300 thousand linear meters [1].

In the oil and gas industry of Uzbekistan, the main indicators characterizing the efficiency of enterprises are: the number of used scientific and technical measures, the costs of their implementation, the resulting economic effect, the additional volume of production 
through the use of scientific and technological developments, the mustering and production of new products and the conditional release of the number of employees. In 2005 - 2017 years were used 929 measures, the actual economic effect of which amounted to 550.5 billion UZS. The implementation of measures allowed to increase profit by 853.1 billion soums, including by reducing costs - by 115.4 billion UZS, of which in 2018 year, respectively, by 175.4 billion UZS and 19 billion UZS. Fuel and energy resources and material and technical resources were saved by 29.9 billion UZS, including 7.3 billion UZS in 2017 (Table 1.) $)^{1}$.

Table 1. Technical and economic indicators of the use of scientific and technological achievements in "Uzbekneftegaz" JSC.
The realization of the intellectual potential of oil and gas industry enterprises was manifested in the development and commissioning of large strategic facilities: the Bukhara oil refinery and the Shurtan gas and chemical complex, the modernization of the Fergana oil refinery complex, the Ustyurt gas and chemical complex. The construction of a gas processing plant at the Kandym field was completed, together with the Russian oil company "LUKOIL". The design for the production of (LNG) liquefied natural gas and (GTL) synthetic liquid fuels is nearing completion (project feasibility study has been prepared on the basis of purified methane). The construction project of the Jizzak oil refinery is being developed. At various stages of implementation are investment projects that play an important role in the development of the fuel and energy complex of Uzbekistan.

\begin{tabular}{|l|c|c|c|c|c|c|c|c|c|}
\hline \multicolumn{1}{|c|}{$\begin{array}{c}\text { Name of } \\
\text { indicators }\end{array}$} & $\begin{array}{c}\text { Unit } \\
\text { meas. }\end{array}$ & $\begin{array}{c}\mathbf{2 0 0 5} \\
\text { year }\end{array}$ & $\begin{array}{c}\mathbf{2 0 1 1} \\
\text { year }\end{array}$ & $\begin{array}{c}\mathbf{2 0 1 2} \\
\text { year }\end{array}$ & $\begin{array}{c}\mathbf{2 0 1 3} \\
\text { year }\end{array}$ & $\begin{array}{c}\mathbf{2 0 1 4} \\
\text { year }\end{array}$ & $\begin{array}{c}\mathbf{2 0 1 5} \\
\text { year }\end{array}$ & $\begin{array}{c}\mathbf{2 0 1 6} \\
\text { year }\end{array}$ & $\begin{array}{c}\mathbf{2 0 1 7} \\
\text { year }\end{array}$ \\
\hline $\begin{array}{l}\text { 1. The number of } \\
\text { STP events used }\end{array}$ & Pcs & 84 & 87 & 75 & 61 & 47 & 54 & 63 & 61 \\
\hline $\begin{array}{l}\text { 2. Actual } \\
\text { economic effect }\end{array}$ & billion UZS & 29 & 38,4 & 28,4 & 24,9 & 18,8 & 112 & 72,5 & 81,4 \\
\hline $\begin{array}{l}\text { including self- } \\
\text { supporting }\end{array}$ & billion UZS & 28,9 & 38,3 & 28,4 & 24,9 & 18,8 & 103,6 & 50,2 & 64,3 \\
\hline $\begin{array}{l}\text { 3. Profit growth } \\
\text { including by } \\
\text { reducing costs }\end{array}$ & billion UZS & 29,1 & 28,8 & 27,5 & 24,9 & 18,8 & 210,5 & 164,7 & 175,4 \\
\hline $\begin{array}{l}\text { 4. Saving fuel and } \\
\text { energy resources, } \\
\text { and material and } \\
\text { technical } \\
\text { resources }\end{array}$ & billion UZS & 28,8 & 5,0 & 5,3 & 0,1 & 0,9 & 2,8 & 6,8 & 2,9 \\
\hline
\end{tabular}

As can be seen from the data, for all indicators except exports, there is a significant increase. The drop in export of products is due to the fact that in recent years one of the main priorities of the economy is to deepen the processing of natural raw materials and the production of alternative fuels to meet the needs of consumers of the Republic.

The effectiveness of using the intellectual capital of "Uzbekneftegaz" JSC in the system of innovative cooperation in education, science and production is evidenced by the dynamics of the final results of the industry for 2007-2016 years (Fig. 1.).

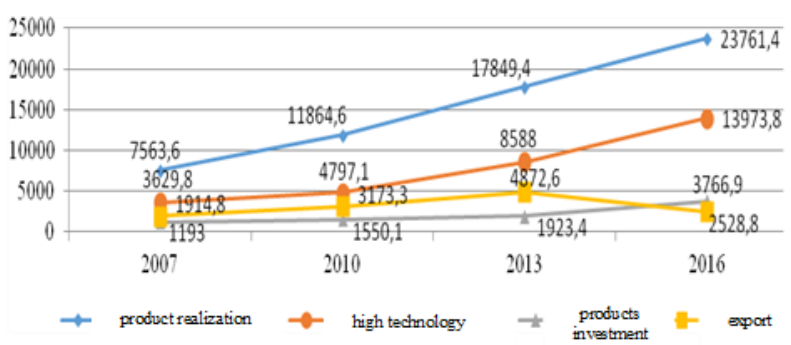

Fig. 1. Dynamics of changes in the volume of product realization, high-tech industrial products, export of products and investment in fixed assets (billion UZS). ${ }^{2}$
The current stage of development of the oil and gas industry of Uzbekistan is characterized by the introduction of new capacities for in-depth processing of hydrocarbon raw materials and bringing the quality of products to the level of world standards.

The Thomson-Reuters World Business Information Agency noted the uniqueness and innovation of the Ustyurt Gas Chemical Complex Construction project, and it was recognized as the best project of the year in the petrochemical industry. According to the rating published by the reputable consulting company "DILOGIC" (Great Britain), the project was included in the list of ten global investment projects in the world.

It should be noted that hydrocarbons mainly dominate in the structure of the energy balance of Uzbekistan - their share is more than $96 \%$. Currently, a number of government decisions have been adopted [24], which will lead to diversification of the energy balance of Uzbekistan. 


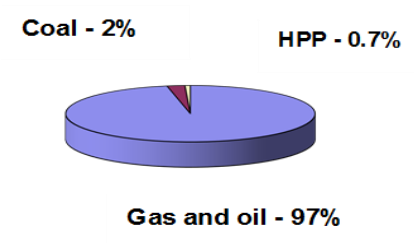

Fig. 2. The structure of the energy balance of the Republic of Uzbekistan [8]

Total energy production: 2018 - 82 million tons of oil equivalent

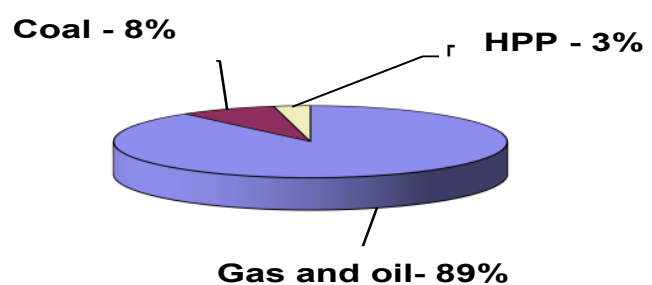

Fig. 2. Forecast of the structure of the energy balance of the Republic of Uzbekistan for 2020. (Forecast by the author)

"Uzbekneftegaz" JSC plans to direct USD 235 million by 2020 to increase oil production at longdeveloped fields in the Republic [4].

It is planned that by 2021 year the Holding will implement a deep drilling program for about 100 facilities with the participation of foreign companies that provide their experience in applying advanced technologies for enhancing oil recovery in fields with difficult to extract reserves. By 2021 year, the holding plans, due to geological and technical measures aimed at compensating for oil production losses, to annually extract an additional 300 thousand tons of oil [5].

It should be noted that investors are interested in joint processing of raw materials, with the release of new types for Uzbekistan, including gas-chemical products. The projects on production of modern oil and gas equipment, rendering of services are considered. Today, among the partners of "Uzbekneftegaz" JSC are the largest companies from China, Malaysia, Korea, Russia and other countries.

Together with a number of foreign partners of China and Russia, the possibilities of producing oil and gas equipment were considered with the prospect of creating several Joint Ventures on the basis of "Uzneftegasmash" JSC. enterprises and including them in the localization program [5].

"Uzbekneftegaz" JSC in 2018 - 2030 years will increase hydrocarbon reserves by 2.2 times - up to 5.6 billion tons of standard fuel. To create a reliable resource base and maintain the level of gas production for the period until 2030 year, it is necessary to annually increase the reserves of raw materials in volumes exceeding their production by 1.1-1.5 times. According to the Holding's calculations, within the framework of the concept of developing the oil and gas industry for the period until 2030 year, it is expected to increase 2.393 trillion $\mathrm{m}^{3}$ of natural gas, oil reserves - 132.4 million tons, condensate - 102.6 million tons. To achieve these goals until 2030 year, it's planned to carry out prospective seismic surveys [6].

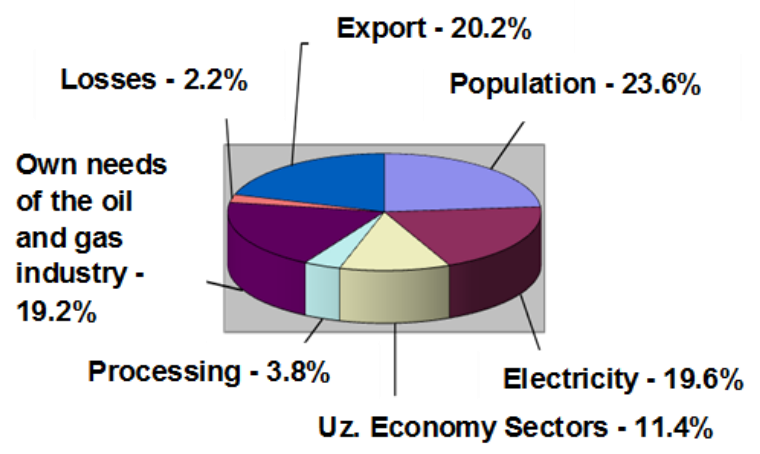

Fig. 3. Usage - the distribution of natural gas by sectors of the economy of Uzbekistan [8]. In fig. 3 shows the structure of natural gas consumption in the sectors of the economy of Uzbekistan.

\section{Key findings and suggestions}

The analysis shows that, with the exception of the Bukhara - Khiva region, in all others, the development in the main productive complexes doesn't exceed 35.5\%, that is, today they are the main objects for placing prospecting volumes in the future. In particular, in the near future exploration work (geological exploration) will be intensified below the underlying strata in the Ustyurt, Bukhara-Khiva, Surkhandarya and Fergana oil and gas regions. To increase the production of petroleum products, a geological exploration program for the search and exploration of heavy oil deposits within the "Besharcha" area in the Surkhandarya region and a geological exploration program for the search and exploration of heavy oil and bitumen deposits within the Fergana region are under development [7].

To increase the production of petroleum products, the development stage includes the exploration program for prospecting and exploring heavy oil deposits within the "Besharcha" area of the Surkhandarya region and the exploration program for exploring and exploring heavy oil and bitumen deposits within the Fergana region [7].

According to the Joint-Stock Company: recoverable proven hydrocarbon reserves in Uzbekistan as on 1 January 2016 year amounted to 2.53 billion tons of oil equivalent tons, of which about $65 \%$ are gas reserves on 1 January 2016 year 242 hydrocarbon deposits were discovered in Uzbekistan, of which 192 were gas. Of the open fields, 104 are under development, 66 are prepared for development, exploration work continues at 72 fields [7].

It should be noted that one of the most promising areas in hydrocarbon production is the processing of oil shale into oil products. "Uzbekneftegaz" JSC plans to set up shale oil production on the basis of the Sangruntau field in the Navoi region of the Republic. The project will be implemented jointly with the Japanese company JGS Corporation [6]. Financing of the project with a preliminary cost of 600 million US dollars is planned to be carried out at the expense of the company's own funds, loans of the Fund for Reconstruction and Development of Uzbekistan and foreign investments in the amount of 300 million US dollars. 
The company provides for the construction of a refinery with a capacity of up to 1 million tons of oil products per year. Estimated reserves of oil shale in Uzbekistan amount to 47 billion tons. In particular, reserves of the Baysun, Urtabulak, Sangruntau, Aktau, Uchkir, Kulbeshkak deposits were estimated in the Republic. In addition to hydrocarbons, in significant quantities there is a wide range of non-ferrous and rare metals.

The output of the diesel fraction from the resin of the shales of the Sangruntau deposit is about $30 \%$, which is the highest indicator among the main deposits of this type in the Republic [7].

Thus, "Uzbekneftegas" JSC pays special attention to the introduction of modern technologies for advanced processing of raw materials and the development of competitive, high-quality products that are in demand on the domestic and foreign markets, contributes to the further diversification of economic structures, ensuring its sustainable and dynamic development, and also contributes to the expansion of export potential of our Republic.

\section{References}

1. http://www.gazoviklpg.ru/about/news/2011/06/28/52/

2. "On measures for the further development of alternative energy sources." Decree of President I. Karimov of March 1, 2013.

3. Decree of the President of the Republic of Uzbekistan No. UP-4947 dated February 7, 2017 "On the action strategy for the further development of the Republic of Uzbekistan".

4. Allaeva G. J. Innovative potential of the fuel and energy complex of the Republic of Uzbekistan. //Monograph. - Tashkent, "Fan va texnologiyalar", 2017. $-160 \mathrm{p}$.

5. http://oilgasfield.ru/news/39490.html

6. http://ruspower.ru/news/202752233

7. Uvraimov I. A. Review of key trends in the global and Central Asian oil and gas market. The Uzbek Journal of Oil and Gas. T., Special Issue, May 2013, p. 28 - 35.

8. Allaev K. R. Energy of the world and Uzbekistan. T., Moliya, 2007, 388 p.

9. Alternative energy sources: opportunities for use in Uzbekistan. Analytical report. Center for Economic Research. UNDP. 2011, 74 p. 